\title{
The Effect of PEEP Adjusted by Automatic Recruitment Maneuver on Total and Dynamic Mechanical Power in Bariatric Surgery
}

\author{
Bariyatrik Cerrahide Otomatik Rekruitment Manevrası ile Ayarlanan PEEP \\ Düzeyinin Total ve Dinamik Güç Üzerine Etkisi
}

\author{
Sinan Aşar¹, (D) Evrim Kucur Tülübaş ${ }^{1}$, (1) Mehmet Süleyman Sabaz², (D) Özlem Acicbe ${ }^{3}$ \\ ${ }^{1}$ University of Health Sciences Turkey, Bakırköy Dr. Sadi Konuk Training and Research Hospital, Clinic of Anesthesiology and Reanimation, İstanbul, Turkey \\ ${ }^{2}$ Marmara University Pendik Training and Research Hospital, Clinic of Anesthesiology and Reanimation, Division of Intensive Care, İstanbul, Turkey \\ 3University of Health Sciences Turkey, Şişli Hamidiye Etfal Training and Research Hospital, Clinic of Intensive Care, İstanbul, Turkey
}

\begin{abstract}
Objective: Mechanical power is a predictor of ventilator-induced lung damage. An automatic recruitment maneuver (ARM) is used during anesthesia to adjust the optimal positive end-expiratory pressure (PEEP) level. This study compared the total mechanical and dynamic power of patients who underwent sleeve gastrectomy due to morbid obesity who are ventilated with PEEP adjusted according to the anesthesiologists' decision and those adjusted using ARM.
\end{abstract}

Methods: Patients between the ages of 18 and 65 years, with American Society of Anesthesiologists (ASA) III and body mass index of $>40$, were divided into two groups: group 1 with PEEP adjusted using the ARM and group 2 without the ARM. Total mechanical power and dynamic power in both groups were calculated using respiratory mechanics measured at 10-min intervals. Patient averages of the calculated power values of both groups were compared with the Mann-Whitney $U$ test.

Results: Simplified mechanical power of pressure control ventilation (MP pcv(simpl) $_{\text {) }}$ (dynamic) resulted 2.9 (2.4-3.4) in group 1 and 7.9 (6.4-9.6) in group $2(p<0,0001) . M P_{\text {pcv(simpl) }}$ (total power) resulted 8.1 (7.4-8.9) in group 1 and 12.8 (9.9-15.2) in group 2 ( $\left.p<0.0001\right)$.

Conclusion: Optimal PEEP adjustment by ARM reduced the lung elastance and DP, resulting in less dynamic power applied to the respiratory system.

Keywords: Obesity, mechanical power, PEEP, recruitment maneuver

\section{öz}

Amaç: Mekanik güç, ventilatörün yol açtığı akciğer hasarını öngörmede kullanılan bir prediktördür. Otomatik rekruitment manevrası (ARM), anestezi sırasında optimal pozitif ekspirasyon sonu basıncı (PEEP) düzeyini tayin etmek amacıyla kullanılmaktadır. Bu çalışmada morbid obezite nedeniyle sleeve gastrektomi uygulanan hastalarda, sabit PEEP uygulanan hastalar ile ARM ile optimal PEEP düzeyi tayin edilen hasta gruplarında hesaplanan total mekanik güç ve elastik güç değerleri karşılaştırıldı.

Gereç ve Yöntem: Vücüt kitle indeksi >40 üzerinde olan Amerikan Anestezi Uzmanları Derneği (ASA) III, 18-65 yaş aralığındaki hastalar iki gruba ayrıldı. Birinci grupta PEEP ayarlaması ARM ile yapıldı. İkinci grupta sabit PEEP değerleri kullanıldı. Her iki grupta 10 dakika aralıkla ölçülen solunum mekanikleri kullanılarak total mekanik güç ve elastik güç değerleri hesaplandı. Hesaplanan mekanik güç değerlerinin hasta ortalamaları Mann-Whitney U testi ile karşılaştırıldı.

Bulgular: Basınç kontrollü havalandırmanın basitleştirilmiş mekanik gücü (MP pcv(simpl) $_{\text {) }}$ (dinamik) birinci grupta 2,9 (2,4-3,4) j/dakika ve ikinci grupta $7,9(6,4-9,6) j /$ dakika $(p<0,0001)$. Total güç $\mathrm{MP}_{\text {pcv(simpl) }}$ (total power) birinci grupta $8,1(7,4-8,9) \mathrm{j} /$ dakika ve ikinci grupta $12,8(9,9-15,2) \mathrm{j} /$ dakika $(p<0,0001)$ olarak hesapland.

Sonuç: ARM kullanılarak yapılan optimal PEEP tayini, akciğer elastans ve sürücü basıncını azaltarak, solunum sistemine uygulanan elastik güç değerini düşürmektedir.

Anahtar Kelimeler: Obezite, mekanik güç, PEEP, rekruitment manevrası

Address for Correspondence: Sinan Aşar, University of Health Sciences Turkey, Bakırköy Dr. Sadi Konuk Training and Research Hospital, Clinic of Anesthesiology and Reanimation, Istanbul, Turkey

Phone: +90 5442659844 E-mail: sinan.asaras@gmail.com ORCID ID: orcid.org/0000-0001-5787-5885

Cite as: Aşar S, Kuçur Tülübaş E, Sabaz MS, Acicbe Ö. The Effect of Adjusted PEEP by Automatic Recruitment Maneuver on Total and Dynamic Mechanical Power in Bariatric Surgery. Med J Bakirkoy 2021;17:262-267

Received: 03.09.2021

Accepted: 20.09.2021 


\section{INTRODUCTION}

Postoperative pulmonary complications are associated with increased morbidity and mortality in patients undergoing surgery (1). Growing evidence showed that lung-protective strategies including low tidal volume, the use of optimal positive end-expiratory pressure (PEEP), and recruitment maneuvers during intraoperative mechanical ventilation reduce postoperative pulmonary complications (2). Mechanical power is an evolving concept in lung-protective ventilation, associated with increased mortality in acute respiratory distress syndrome and non-injured lungs (3).

Nowadays, the number of patients who undergo bariatric surgery is increasing due to increasing morbid obesity. Patients with obesity are at risk for developing ventilatorinduced lung injury (VILI) since they are ventilated at high pressures due to a stiff chest wall and abdominal fat mass. Applying PEEP in patients with obesity avoids alveoli closure by keeping the alveolar pressure above the closing pressure. Alveolar closing pressures are high due to the chest wall pressure on the pleural space (4).

Mechanical power, which gathers different variables such as tidal volume, driving pressure (DP), flow, respiratory rate (RR), and PEEP in a single parameter, is related to VILI in various studies, offering new possibilities in VILI prediction at the bedside (5-8). The formula mechanical power (MPrs) developed by Gattinoni et al. (8) is based on the motion equation, although with all VILI variables, is too complex for practical use and is only used in volume-controlled ventilation. Becher et al. (9) proposed a simplified equation (MPpcv(simpl)) and a more comprehensive formula (MPpcv(slope)) to calculate the mechanical power in pressure control ventilation (PCV).

Recently, mechanical power showed an association with VILI and mortality $(8,10,11)$. DP is considered the most important factor in VILI (12-14). However, mechanical power is more important as it takes other respiratory mechanics (PEEP, RR, and time) into account (5). The contribution of DP to power is also calculated as dynamic power (15). The negative and positive contribution of PEEP to power is currently discussed. Beyond applying and not applying PEEP, concepts of good PEEP (best PEEP) and bad PEEP (worst PEEP) were introduced $(4,16,17)$. Thus, how to use PEEP? How to distinguish between good PEEP and bad PEEP? Particularly, can anesthesia safety be increased with the best PEEP in anesthesia applications?

This study aimed to evaluate the use of automatic recruitment maneuver (ARM) to set an optimal PEEP level to reduce the mechanical power, VILI, and postoperative pulmonary complications. The study was conducted in patients with obesity who underwent bariatric surgery. Total mechanical and dynamic power were compared between patients who were ventilated with PEEP set without ARM and patients whose optimal PEEP level were adjusted using ARM.

\section{METHODS}

Adult patients aged 18-65 years, with American Society of Anesthesiologists (ASA) III and body mass index (BMI) of $>40$, signed a voluntary informed consent form and were included in the study. Inclusion criteria are as follows: Without alcohol or drug addiction, without chronic obstructive pulmonary disease diagnosis by a pulmonogist during the preoperative routine evaluation, with normal FEV1/FVC ratio, FEV1, and FVC values, and without history of abdominal surgery. STOPBANG assessment test was performed on each pre-op patient. Spirometry was performed by a single anesthesiologist on the day of surgery and FEV1, FVC, and FEV1/FVC ratio of all patients were recorded. Patients with normal FEV1 and FVC were included in the study.

Three-lead electrocardiogram, pulse oximetry, non-invasive blood pressure, bispectoral index (BIS) and train of four monitoring were applied to all patients after placing them on the operating table in a ramp position.

Propofol between 2 and $3 \mathrm{mg} / \mathrm{kg}$ was administered according to the ideal weight and in a manner BIS score at $40-60$ and rocuronium at $0.5 \mathrm{mg}$ and fentanyl at $150 \mathrm{mcq}$ were intravenously administered according to the ideal weight. Patients were ventilated with $6 \mathrm{~L} / \mathrm{min}$ of $60 \%$ oxygen $\left(\mathrm{O}_{2}\right)$ for 2 min. Patients were endotracheally intubated using the Macintosh Laryngoscope.

After intubation, $50 \mathrm{mg}$ of ranitidine and $8 \mathrm{mg}$ of ondansetron were routinely administered. The remifentanil dose was kept and infusion was performed at a rate of $0.1 \mathrm{mcg} / \mathrm{kg} /$ min. Sevoflurane percentage was maintained by changing the minimum alveolar concentration (MAC) value from 0.6 to 1.1 in a way that the BIS score was between 40 and 60 .

Patients were divided into two groups: group 1 applied with PEEP adjusted using ARM and group 2 without ARM. Both groups were given $3 \mathrm{~L} / \mathrm{min}$ of fresh gas flow $\left(50 \% \mathrm{O}_{2}, 50 \%\right.$ air) and ventilated in pressure-regulated volume control (PRVC) mode with Maquet Flow-i (Sweden). Tidal volume was set at 6-8 $\mathrm{mL}$ according to the ideal weight, $\mathrm{FiO}_{2}$ at $40 \%$, and RR according to end-tidal carbon dioxide $\left(\mathrm{EtCO}_{2}\right)$.

Group 1 received incremental ARM twice after insufflation and desufflation so that the target peak pressure (Ppeak) 
reached $40 \mathrm{~cm} \mathrm{H}_{2} \mathrm{O}$ and the target PEEP at $20 \mathrm{~cm} \mathrm{H}_{2} \mathrm{O}$. The $P E E P$ value at which the highest dynamic compliance (Cdyn) was measured during ARM was considered the ideal PEEP for the patient, and PEEP after ARM was set at this value. PEEP set without ARM was set according to the anesthesiologists' decision in group 2. MAC, BIS, mean arterial pressure (MAP), heart rate, oxygen saturation $\left(\mathrm{sPO}_{2}\right), \mathrm{EtCO}_{2}, \mathrm{RR}$, Ppeak, PEEP, and compliance (C) values were recorded for both groups every $10 \mathrm{~min}$ peroperatively. Elastance (ELrs) was measured with inspiratory and expiratory hold maneuvers simultaneously (every $10 \mathrm{~min}$ ) and values were recorded.

Remifentanyl was discontinued 10 min before the end of the operation in both groups. Afterwards, $1 \mathrm{~g}$ of paracetamol and $100 \mathrm{mg}$ of tramadol were intravenously administered. Sugammadex at $2 \mathrm{mg} / \mathrm{kg}$ was administered according to the ideal weight at the end of the surgery. When the trigger was zero, patients were extubated when they achieved sufficient tidal volume, with a BIS score between 80 and 100 . Patients with an ARISCAT Risk index of $9 \geq 9$ in the review were sent to the floor.

Vital signs, including MAP, were monitored postoperatively. Tenoxicam at $20 \mathrm{mg}$ was administered intravenously in the first hour. The patient-controlled analgesia device was set in a way that tramadol at $300 \mathrm{mg} / 100 \mathrm{~mL}$ : Bolus as $10 \mathrm{mg}$, lock time as $12 \mathrm{~min}$, and no basal infusion is administered. Patients with Numeric Rating scale scores of $\geq 4$ were intravenously given with $4 \mathrm{mg}$ of morphine as a salvage dose.

Analgesia was provided 24 hours after surgery, maintaining the visual analog scale (VAS) score at $<4$, and spirometry was repeated by the same doctor before the surgery.

\section{Patient Randomization}

In the study, random numbers were generated to prevent selection bias. Of the produced numbers, 0 was predetermined as control and 1 was predetermined as the experimental group, and patients were assigned to groups in this direction. Random numbers were made with the program MedCalc 18.2.1. (MedCalc Statistical Software version 18.2.1 MedCalc Software bvba, Ostend, Belgium; http://www.medcalc.org; 2018).

Group 1 was defined as patients who received PEEP with ARM and group 2 as patients who received PEEP without ARM.

\section{Mechanical Power Calculation:}

The power calculations in this study were also calculated with Becher's simple formula (pressure control simplified mechanical power equation, $\mathrm{MP}_{\text {pcv(simpl) }}$ (9).

$\mathrm{MP}_{\text {pcysimpl) }}$ (total power) $(\mathrm{J} / \mathrm{min})=0.098 \times \mathrm{RR} \times \mathrm{TV} \times(\mathrm{DP}+$ PEEP)

$\mathrm{MP}_{\text {pcv(simpl) }}($ Dynamic power) $=0.098 \times \mathrm{RR} \times \mathrm{TV} \times \mathrm{DP}$

$\mathrm{DP}=$ Ppeak-PEEP and 0.098 is the conversion factor to Joule

Since the tidal gas flow and inspiratory resistance (Ri) cannot be measured in PRVC mode, the resistive component of the mechanical power between the two groups is not calculated.

PRVC mode is a PCV mode. Assuming no intrinsic PEEP, airway pressure in PCV was considered constant at the end of inspiration, with equal Ppeak and alveolar pressure (Pplateau) (Pplateau = Ppeak) (18-21).

If $D P=P_{\text {plateau }}-P E E P=P_{\text {peak }}-P E E P$, then $C=\Delta V / D P$

Total MPrs and the dynamic component of power were calculated using respiratory mechanics measured at 10-min intervals. Patient averages of the calculated power values were statistically analyzed.

\section{Statistical Analyses}

GraphPad Prism (v 5.01) program was used for statistical analysis of obtained study findings. Results of the ShapiroWilk normality test did not conform to the normal distribution of numerical variables in the two groups, thus the MannWhitney $U$ test was used for binary variable comparison. Categorical variables were evaluated using the chi-square and Fisher's Exact test. Median and interquartile range $(I Q R)$ values were taken as a basis for statistical evaluation. Statistical values of $p<0.05$ were considered significant.

The necessary data were recorded peroperative for each patient for $90 \mathrm{~min}$ and once every $10 \mathrm{~min}$. A total of 954 measurements were made for a total of 106 patients, wherein 56 are from group 1 and 50 from group 2. Data were saved based on excel. Statistical analyzes were made according to patient averages.

Total mechanical power values are calculated as MPpcr (simpl) formula, which is the primary outcome of the preliminary study (first 10 patients). Mean and standard deviation values for group 1 were calculated as $8.1 \pm 3.2 \mathrm{~J} /$ min and $10.5 \pm 3.1 \mathrm{~J} / \mathrm{min}$ for group 2. The standard error margin (Alpha error) was calculated as 0.05 and $95 \%$ and the effect size was calculated as 0.6 in the power analysis made according to the power difference, the number of required patients in the study was calculated as 50 patients for each group (G*Power 3.1.9.4).

Institutional permission and ethical approval from the University of Health Sciences Turkey, Bakırköy Dr. Sadi Konuk Training and Research Hospital, Clinical Research 
Ethics Committee were obtained from where the study was conducted before it begins (protocol code: 2018/474, decision number: 2018-23-21 and approval date: 17.12.2018). Written, informed consent was obtained from all patients. All methods were carried out by relevant guidelines and regulations.

\section{RESULTS}

Group 1 includes 50 patients and group 2 had 56 patients. Patient characteristics revealed no statistically significant difference between gender, age, BMI, duration of surgery, MAP, heart rate, Ariskat score, and postoperative 1, 6, and 24-hour VAS scores ( $p>0.05)$. STOPBANG scale was significantly higher in group 2 than that of group $1(p=0.004)$ (Table 1). The respiratory parameters evaluated three stages (after induction of anesthesia, before insufflation, after desufflation) in the peroperative process: Average during the operation (Perop. mean). Compliance, ELrs, PEEP, Ppeak, $\mathrm{SpO}_{2}, \mathrm{DP}$, and total and dynamic mechanical power Perop. mean values were statistically significant (Table 2 ). The difference of PEEP, DP, and total and dynamic power values was statistically significant between the two groups $(p<0.0001)$.

\section{DISCUSSION}

This study observed that the ARM, which improves respiratory mechanics and oxygenation, did not significantly change the hemodynamic parameters. However, without difference between the pulmonary function tests in both groups, the dynamic mechanical power values were lower in patients where PEEP was adjusted with an ARM than in patients without ARM. The dynamic power difference between the two groups was dependent on the difference in PEEP. Energy applied (dynamic) to the respiratory system was significantly less in the group in which PEEP was applied with ARM. No difference was found between the two groups in terms of RR and tidal volumes; however, PEEP was higher in the group with ARM, which was due to low Ppeak and much lower DP values. Lower DP values mean higher compliance and naturally lower lung ELrs.

PEEP significantly contributes to lung-protective ventilation by reducing lung ELrs in patients with obesity. Particularly,

Table 1. Patient characteristics

\begin{tabular}{|c|c|c|c|}
\hline Patient median (IQR) & $\begin{array}{l}\text { Group } 1 \text { (PEEP with ARM) } \\
(n=56)\end{array}$ & $\begin{array}{l}\text { Group } 2 \text { (PEEP without ARM) } \\
(n=50)\end{array}$ & $\mathrm{p}$ \\
\hline Gender, female no (\%) & $54(96 \%)$ & 37 (74\%) & 0.47 \\
\hline Age median (year) & $39(31-47)$ & $41(35-48)$ & 0.40 \\
\hline BMI $\left(\mathrm{kg} / \mathrm{m}^{2}\right)$ & $45.2(41.8-50.2)$ & $46.2(43.2-50.5)$ & 0.49 \\
\hline Operating time (min) & $58(53.7-70)$ & $56(50-65)$ & 0.426 \\
\hline MAP Perop, mean $(\mathrm{mmHg})$ & $84.1(75.2-92.8)$ & $85.2(77.7-95.4)$ & 0.3189 \\
\hline HR Perop, mean (1/min) & $84.8(78.8-97.3)$ & $88.2(80.8-95.4)$ & 0.3876 \\
\hline Ariskat score & $15(15-15)$ & $15(15-17)$ & 0.162 \\
\hline Postop 1 hour VAS score & $3(2-4)$ & $3(2-4.2)$ & 0.255 \\
\hline Postop 6 hour VAS score & $2(1.2-3)$ & $3(2-3)$ & 0.306 \\
\hline Postop 24 hour VAS score & $1(0-2)$ & $2(0-2)$ & 0.078 \\
\hline STOPBANG score & $3(3-4)$ & $4(3-5)$ & 0.004 \\
\hline FEV1 preoperative $(\mathrm{mL})$ & $84(77-95)$ & $85(76-92)$ & 0.8 \\
\hline FEV1 postoperative (mL) & $72(64-85)$ & $71(68-83)$ & 0.9 \\
\hline FVC preoperative (mL) & $81(71-90)$ & $80(70-90)$ & 0.8 \\
\hline FVC postoperative $(\mathrm{mL})$ & $75(64-83)$ & $72(67-79)$ & 0.3 \\
\hline FEV1/FVC preoperative (\%) & $1.10(1.01-116)$ & $1.06(1.01-1.14)$ & 0.4 \\
\hline FEV1/FVC postoperative (\%) & $1.03(0.97-1.12)$ & $1.05(0.98-1.11)$ & 0.6 \\
\hline \multicolumn{4}{|c|}{$\begin{array}{l}\text { The Mann-Whitney } U \text { test was used to analyze the parameters shown in the table between the groups and the chi-square test was used to determine the } \\
\text { percentage and significance level of gender difference. PEEP with ARM: The group upon whom PEEP is applied with ARM PEEP without ARM: The group upon } \\
\text { which positive end-expiratory pressure is applied according to the anesthesiologists' decision. IQR: Interquartile range, BMI: Body mass index, MAP: Mean } \\
\text { arterial pressure, HR: Heart rate, VAS: Visual analog scale, STOPBANG score: Score of obstructive sleep apnea score, FEV } \text { F Forced expiratory volume in one }_{\text {second, FVC: Forced vital capacity }}\end{array}$} \\
\hline
\end{tabular}


Table 2. Respiratory parameters

\begin{tabular}{|c|c|c|c|}
\hline $\begin{array}{l}\text { Patient } \\
\text { Median (IQR) }\end{array}$ & $\begin{array}{l}\text { Group } 1 \text { (PEEP with ARM) } \\
(n=56)\end{array}$ & $\begin{array}{l}\text { Group } 2 \text { (PEEP without ARM) } \\
(n=50)\end{array}$ & $p$ \\
\hline Cstatik perop. mean & $44.1(36.0-51.4)$ & $38.2(33.6-44.8)$ & 0.0422 \\
\hline Elastance perop. mean & $22.7(19.4-27.7)$ & $26.1(22.2-29.7)$ & 0.0421 \\
\hline Cdynamic perop. mean & $40.0(32.8-48.3)$ & $36.07(31.6-40)$ & 0.0248 \\
\hline PEEP perop. mean & $8(7-10.2)$ & $7(6-8)$ & 0.0049 \\
\hline Ppeak perop. mean & $19.8(18.6-22.1)$ & $21.7(20.5-23.7)$ & 0.0005 \\
\hline RR perop. mean & $14(13-14)$ & $14(13-14)$ & 0.0647 \\
\hline TV perop. mean & $440(402-480)$ & $470(400-520)$ & 0.2440 \\
\hline $\mathrm{EtCO}_{2}$ perop. mean & $40.7(38.1-42.5)$ & $41.07(38-42.5)$ & 0.7928 \\
\hline $\mathrm{SpO}_{2}$ perop. mean & $97.7(96.7-98.5)$ & $96.5(95.3-97.2)$ & $<0.0001$ \\
\hline Pplato perop. mean & $18.4(16.6-20.6)$ & $20.3(18.2-23.5)$ & 0.0008 \\
\hline DP perop. mean & $11.14(9.3-13.7)$ & $14.43(12.8-16.7)$ & $<0.0001$ \\
\hline $\mathrm{MP}_{\text {pcv(simpl) }}$ (total power) perop. mean & $8.1(7.4-8.9)$ & $12.8(9.9-15.2)$ & $<0.0001$ \\
\hline $\begin{array}{l}\mathrm{MP}_{\text {pcv(simpl) }} \text { (dynamic component) } \\
\text { Perop. mean }\end{array}$ & $2.9(2.4-3.4)$ & $7.9(6.4-9.6)$ & $<0.0001$ \\
\hline
\end{tabular}

Mann-Whitney $\mathrm{U}$ test was used to analyze the parameters shown in the table between the groups. IQR: Interquartile range, (Cstatic: Static compliance ( $\mathrm{mL}$ / $\left.\mathrm{cmH}_{2} \mathrm{O}\right)$, Elastance $\left(\mathrm{cmH}_{2} \mathrm{O} / \mathrm{L}\right)$, Cdynamic: Dynamic compliance $\left(\mathrm{mL} / \mathrm{cmH}_{2} \mathrm{O}\right), \mathrm{PEEP}$ : Positive end-expiratory pressure $\left(\mathrm{cmH}_{2} \mathrm{O}\right)$, Ppeak: Peak pressure $\left(\mathrm{cmH}_{2} \mathrm{O}\right)$, RR: Respiratuar rate (1/minute), TV: Tidal volume $(\mathrm{mL}) \mathrm{ETCO}_{2}$ : End-Tidal $\mathrm{CO}_{2}\left(\mathrm{mmHg}, \mathrm{SpO}_{2}\right.$ : Oxygen saturation (\%), Pplato: Peak pressure (cmH $\left.\mathrm{H}_{2} \mathrm{O}\right), \mathrm{DP}: \mathrm{Driver}$ pressure $\left(\mathrm{cmH}_{2} \mathrm{O}\right), \mathrm{MP}_{\text {pcusimpl) }}(\mathrm{J} /$ minute): Simplified mechanical power of pressure control ventilation)

PEEP reduces lung damage by decreasing DP $(8,17)$. Patients with PEEP adjusted according to ARM were ventilated with higher PEEP values than patients with PEEP set without ARM, thus lower ELrs values were calculated. PEEP reduces $D P$, one of the important components of mechanical power, which is the cause of VILI, thus decreases the dynamic component of mechanical power. Administration of PEEP with ARM reduces VILI in patients with obesity. Therefore, optimal compliance values are obtained with a more open lung, and patients are operated on with less peroperative and postoperative lung complications (less atelectasis) (4). Peroperative optimal PEEP application with ARM in patients with obesity who are prone to atelectasis is a feasible solution to achieve a lung-protective ventilation strategy.

Appropriate PEEP usage (higher PEEP) and lower power values, similar $\mathrm{EtCO}_{2}$, and better $\mathrm{SpO}_{2}$ values were obtained in group 1 than that in group 2. A recent study comparing patients with obesity, morbidly obesity, and non-obesity in intensive care observed that patients with morbidly obesity had higher DP and dynamic power but lower $\mathrm{PaO}_{2} / \mathrm{FiO}_{2}$ ratios compared to other patients (22).

Dynamic power is an indicator of the combined effect of all variables involved in the pathogenesis of $\mathrm{VILI}$, thus adjusting PEEP in patients with obesity with ARM in bariatric surgery reduced lung damage. Patients with obesity developed atalectasis and alveolar closure due to a stiff chest wall, and individualized PEEP adjustment with ARM increased the anesthesia safety by reducing the energy applied to the respiratory system and lung damage. An analysis of patients with obesity who underwent elective laparoscopic surgery compared the fixed and individualized PEEP determined by electrical impedance tomography. Better oxygenation, lower $\mathrm{DP}$, and redistribution of ventilation toward dependent lung areas were found in patients with individualized PEEP (23).

\section{Study Limitations}

Patients were not screened for postoperative complications, such as atelectasis, pneumonia, or pulmonary embolism. In addition, the effect of PEEP levels on arterial blood gases was not evaluated.

\section{CONCLUSION}

Appropriate PEEP adjustment with ARM reduced the lung ELrs and DP, and less dynamic power was applied to the respiratory system in patients with obese who were prone to atelectasis due to a stiff chest wall. This approach provides a safer ventilation strategy and contributes to the prevention of VILI and postoperative pulmonary complications.

\section{ETHICS}

Ethics Committee Approval: Institutional permission and ethical approval from the University of Health Sciences 
Turkey, Bakırköy Dr. Sadi Konuk Training and Research Hospital, Clinical Research Ethics Committee were obtained from where the study was conducted before it begins (protocol code: 2018/474, decision number: 2018-23-21 and approval date: 17.12.2018).

Informed Consent: Written, informed consent was obtained from all patients.

\section{Authorship Contributions}

Surgical and Medical Practices: S.A., E.K.T., M.S.S., Concept: S.A., E.K.T., M.S.S., Design: S.A., E.K.T., M.S.S., Data Collection or Processing: S.A., E.K.T., M.S.S., Analysis or Interpretation: S.A., E.K.T., M.S.S., Ö.A., Literature Search: S.A.,Ö.A., E.K.T., M.S.S., Writing: S.A., E.K.T., M.S.S., Ö.A.

Conflict of Interest: No conflict of interest was declared by the authors.

Financial Disclosure: The authors declared that this study received no financial support.

\section{REFERENCES}

1. Canet J, Gallart L, Gomar C, Paluzie G, Vallès J, Castillo J, et al. Prediction of postoperative pulmonary complications in a population-based surgical cohort. Anesthesiology 2010;113:133850.

2. Serpa Neto A, Hemmes SN, Barbas CS, Beiderlinden $M$, Fernandez-Bustamante A, Futier E, et al. Incidence of mortality and morbidity related to postoperative lung injury in patients who have undergone abdominal or thoracic surgery: a systematic review and meta-analysis. Lancet Respir Med 2014;2:1007-15.

3. Alencar R, D'Angelo V, Carmona R, Schultz MJ, Serpa Neto A. Patients with uninjured lungs may also benefit from lung-protective ventilator settings. F1000Res 2017;6:2040.

4. De Jong A, Wrigge H, Hedenstierna G, Gattinoni L, Chiumello D, Frat JP, et al. How to ventilate obese patients in the ICU. Intensive Care Med 2020;46:2423-35.

5. Kumar A, Pontoppidan H, Falke KJ, Wilson RS, Laver MB. Pulmonary barotrauma during mechanical ventilation. Crit Care Med 1973;1:181-6.

6. Dreyfuss D, Soler P, Basset G, Saumon G. High inflation pressure pulmonary edema. Respective effects of high airway pressure, high tidal volume, and positive end-expiratory pressure. Am Rev Respir Dis 1988;137:1159-64.

7. Hotchkiss JR Jr, Blanch L, Murias G, Adams AB, Olson DA, Wangensteen $O D$, et al. Effects of decreased respiratory frequency on ventilator-induced lung injury. Am J Respir Crit Care Med 2000;161:463-8.
8. Gattinoni $L$, Tonetti $T$, Cressoni $M$, Cadringher $P$, Herrmann $P$, Moerer $O$, et al. Ventilator-related causes of lung injury: the mechanical power. Intensive Care Med 2016;42:1567-75.

9. Becher T, van der Staay M, Schädler D, Frerichs I, Weiler N. Calculation of mechanical power for pressure-controlled ventilation. Intensive Care Med 2019;45:1321-3.

10. Cressoni M, Gotti M, Chiurazzi C, Massari D, Algieri I, Amini M, et al. Mechanical Power and Development of Ventilator-induced Lung Injury. Anesthesiology 2016;124:1100-8.

11. Neto AS, Jaber $S$. What's new in mechanical ventilation in patients without ARDS: lessons from the ARDS literature. Intensive Care Med 2016;42:787-9.

12. Amato MB, Meade MO, Slutsky AS, Brochard L, Costa EL, Schoenfeld DA, et al. Driving pressure and survival in the acute respiratory distress syndrome. N Engl J Med 2015;372:747-55.

13. Guérin C, Papazian L, Reignier J, Ayzac L, Loundou A, Forel JM; investigators of the Acurasys and Proseva trials. Effect of driving pressure on mortality in ARDS patients during lung protective mechanical ventilation in two randomized controlled trials. Crit Care 2016;20:384.

14. Bellani G. How respiratory mechanics are associated with outcome. Presented at: e-ISICEM. International Symposium on Intensive Care and Emergency Medicine. 20 September 2020

15. Schaefer MS, Loring SH, Talmor D, Baedorf-Kassis EN. Comparison of mechanical power estimations in mechanically ventilated patients with ARDS: a secondary data analysis from the EPVent study. Intensive Care Med 2021;47:130-2.

16. Marini JJ, Rocco PRM. Which component of mechanical power is most important in causing VILI? Crit Care 2020;24:39.

17. Dries DJ, Marini JJ. Finding Best PEEP: A Little at a Time. Respir Care 2020;65:722-4.

18. van der Meijden S, Molenaar M, Somhorst P, Schoe A. Calculating mechanical power for pressure-controlled ventilation. Intensive Care Med 2019;45:1495-7.

19. Marini JJ, Crooke PS 3rd. A general mathematical model for respiratory dynamics relevant to the clinical setting. Am Rev Respir Dis 1993; 147:14-24.

20. Silva PL, Ball L, Rocco PRM, Pelosi P. Power to mechanical power to minimize ventilator-induced lung injury? Intensive Care Med Exp 2019;7(Suppl 1):38.

21. Ashworth L, Norisue Y, Koster M, Anderson J, Takada J, Ebisu H. Clinical management of pressure control ventilation: An algorithmic method of patient ventilatory management to address "forgotten but important variables". J Crit Care 2018;43:169-82.

22. Syed MKH, Selickman J, Evans MD, Dries D, Marini JJ. Elastic Power of Mechanical Ventilation in Morbid Obesity and Severe Hypoxemia. Respir Care 2021;66:626-34.

23. Simon P, Girrbach F, Petroff D, Schliewe N, Hempel G, Lange M, et al. Individualized versus Fixed Positive End-expiratory Pressure for Intraoperative Mechanical Ventilation in Obese Patients: A Secondary Analysis. Anesthesiology 2021;134:887-900. 